\title{
Enhanced coal bed methane (ECBM) recovery: optimization of CBM production using different injected gas composition and rate for south sumatra CBM field, Indonesia
}

\author{
Abdul Wahid $^{1, *}$, Fariz Adriansyah Putra ${ }^{1}$, Muhamad Taufiq Hidayat $^{1}$, and Muhammad Yusuf $^{2}$ \\ ${ }^{1}$ Chemical Engineering Department, Universitas Indonesia, Depok, Indonesia \\ ${ }^{2}$ Petroraya Consulting, Wisma Raharja, 1st Floor, J1. T.B. Simatupang Kav.1, Jakarta, 12560, Indonesia
}

\begin{abstract}
Indonesia, whose $453 \mathrm{TCF}$ potential coal bed methane (CBM) reserves, rank the 6th largest CBM reserves around the world. However, the technical limitation is amongst the major issues slowing down the exploitation progress of the resources which current national CBM production only reach up to 1 MMSCFD. This paper provides a newly enhanced coal bed methane (ECBM) recovery method to improve the methane production. Scenarios of nitrogen $\left(\mathrm{N}_{2}\right)$ and carbon dioxide $\left(\mathrm{CO}_{2}\right)$ injection were used in this study to perform 25 years production simulation and compared with CBM primary production. Created hypothetical model based on the characteristic of coal seams CBM field in South Sumatra, Indonesia, was used to analyze the increasing methane production by using $\mathrm{N}_{2}$ and $\mathrm{CO}_{2}$ injection with different compositions and rates. The result observed about $3,52 \%$ incremental methane production by injecting $\mathrm{N}_{2}$ into CBM reservoir. In other words, this new method has an impact on enhancing the CBM national production, particularly South Sumatra CBM field, which could be useful for further CBM development in Indonesia. Mixture injection seemed to be unfavorable for the field due to the difference of gas mechanism. Thus
\end{abstract}

\section{Introduction}

Indonesia has CBM potential resources which are spreadly located inside the various basins with total resources of $453 \mathrm{TCF}$ and South Sumatera is considered as the biggest CBM resources with about $183 \mathrm{TCF}$ or almost $41 \%$ out of total resources in Indonesia [1]. There have been some opportunities in developing CBM. Firstly, Indonesia has a favorable geological condition for CBM production. Secondly, CBM basins are mostly in Sumatra and Kalimantan which its market and infrastructure have been growing rapidly over the past decade. Lastly, increasing gas demand. CBM, remarkable as for low-cost alternative resources, will play a key role in fulfilling future national gas demand. Apart from the high potential resource, Barriers has existed in the development stage. One of them is the rate of production. Unlike conventional gas, CBM well produces the gas at lower rates due to its low permeability. The phenomenon causes the investor to deal with the setting of production strategy.

It is important to note that the behavior of the CBM production is very different from the conventional gas reservoir production. CBM production goes through three main stages as illustrated in Figure 1 [2]. Stage 1 Dewatering Stage: This initial stage is characterized by constant water production rates to reduce the reservoir pore pressure, and the initial water production is generally much higher than the methane production. However, this production decreases with time with the increasing of methane production. Stage 2 - Production Stage: This phase is characterized by declining water production rate. On the other hand, methane production becomes maximum and begin to stabilize. Stage 3 - Declining Stage: This stage begins when the well has reached the peak gas rate, and gas production shows a declining trend. During this stage, water production becomes a minimum negligible amount and methane production decreases until it uneconomical to produce.

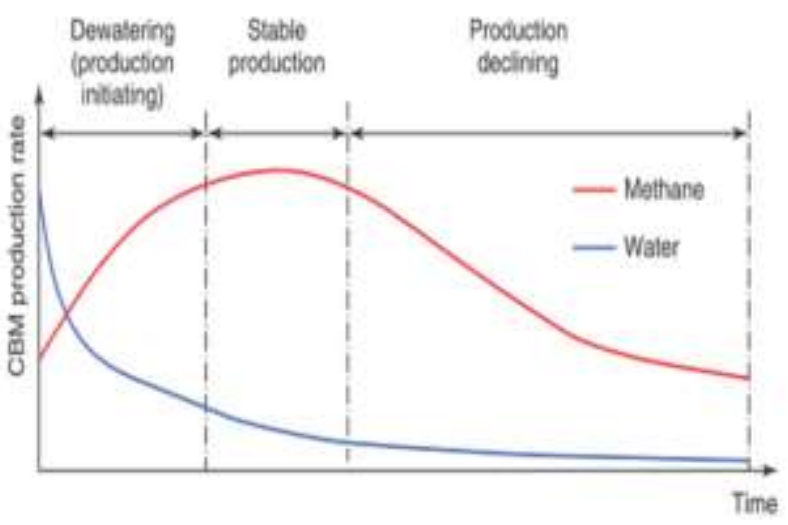

Fig. 1. Production Stages in CBM Development

Although methane $\left(\mathrm{CH}_{4}\right)$ can be obtained in a costeffective manner from suitable seams, towards the end of the lifetime of a CBM project, the pressure decreases and

* Corresponding author: wahid@che.ui.ac.id 
eventually becomes insufficient to make the extraction economically viable. Injecting gas down to the seam can help produce $\mathrm{CH}_{4}$ that would otherwise have been inaccessible. In a mature oil field over half of the original reserve of oil is retained in the reservoir after primary and secondary recovery. Such reserves may be recovered by tertiary recovery schemes through enhanced oil recovery (EOR) techniques, such as chemical flooding. As one of the injected chemicals in chemical flooding, surfactants have a role to play in releasing the trapped oil by lowering the interfacial tension between oil and water [3]. Meanwhile in CBM Field, there are some similar techniques to optimize the hydrocarbon production. The process of injecting a gas or a mixture of gases into a coal seam with the purpose of enhancing methane production is widely known as Enhanced Coalbed Methane (ECBM) recovery, and to date, two main recovery techniques have been tested in the field: $\mathrm{CO}_{2}-\mathrm{ECBM}$ and $\mathrm{N}_{2}$-ECBM. These techniques are discussed in detail in the following sections. Nitrogen $\left(\mathrm{N}_{2}\right)$ and carbon dioxide $\left(\mathrm{CO}_{2}\right)$ injection have been a subject of ECBM and carbon capture and storage (CCS) research during the past decade. $\mathrm{N}_{2}$ and $\mathrm{CO}_{2}$ injection produce substantially different recovery processes. Coal has a higher affinity for $\mathrm{CO}_{2}$ as compared to methane $\left(\mathrm{CH}_{4}\right)$. When $\mathrm{CO}_{2}$ is injected into a coal reservoir, it is preferentially adsorbed onto the coal matrix after having displaced the existing methane in place. The displaced methane diffuses into the cleat system, travels to the lower pressure area where the production well is located and is produced.

Injecting $\mathrm{CO}_{2}$ into coal seams remarked as $\mathrm{CO}_{2}$ ECBM. In contrast, $\mathrm{N}_{2}$-ECBM operates in a different way. N2 increases cleat permeability because of its lower coal storage capacity relative to methane. As a result, injectivity increases during $\mathrm{N}_{2}$-ECBM. According to existing studies, for each volume of injected nitrogen, two volumes of methane can be produced, which implies that coals tend to replace up to $50 \%$ of their methane storage capacity with nitrogen [4]. However, the $\mathrm{N}_{2}$-ECBM technique also involves quicker $\mathrm{N}_{2}$ breakthroughs in the produced gas due to its freely existing nature inside the seam, which causes the benefits offered by the process to be largely reduced when the higher gas treatment costs are considered [5].

Several studies and pilot projects of CBM are now being conducted in South Sumatra and Kutai Basin, but there have been no publications about potential $\mathrm{CO}_{2}$ and $\mathrm{N}_{2}$ injection into coal seams to enhance methane recovery [6-9]. This paper concentrates on the improvement of ECBM by optimization of the injected gas composition (a mixture of $\mathrm{CO}_{2}$ and $\mathrm{N}_{2}$ ) and rates for South Sumatra CBM field. To facilitate industry realization of the benefits of the improved knowledge of ECBM processes resulting from this study, some models were developed to predict the performance of ECBM under a broad set of reservoir conditions, parameters and operating assumption. The results present the optimum mixture of $\mathrm{CO}_{2}$ and $\mathrm{N}_{2}$ required to maximize incremental methane recovery for South Sumatra field.

\section{Methodology}

\subsection{Model construction}

A numerical modelling simulator for unconventional gas reservoirs was utilized to perform this work. Hypothetical model is developed by combining all supporting data from actual field report and literature study. A single layer (83feet thick at an average depth of 2200 feet), composed of five vertical wells; four producers, and one injector, located in centre of the grid, was created as illustrated in Figure 2.

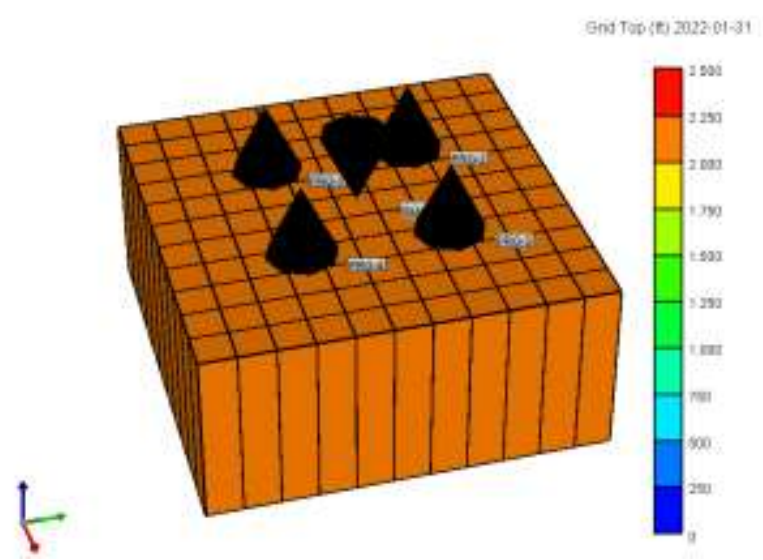

Fig. 2. Constructed Hypothetical Model

Table 1. Reservoir parameters

\begin{tabular}{|l|c|c|}
\hline \multicolumn{1}{|c|}{ Reservoir Parameters } & Dimension & Value \\
\hline Surface area & Acre & 30.63 \\
\hline Coal thickness & $\mathrm{ft}$ & 83.46 \\
\hline Coal density & $\mathrm{lb} / \mathrm{ft}^{3}$ & 91.10 \\
\hline Coal compressibility & $1 / \mathrm{psi}$ & $3 \mathrm{e}-06$ \\
\hline Gas saturation & Fraction & 0 \\
\hline Water saturation & Fraction & 0.9 \\
\hline Water saturation fracture & Fraction & 1 \\
\hline Water viscosity & $\mathrm{cP}$ & 0.71 \\
\hline Matrix porosity & Fraction & 0.01 \\
\hline Fracture porosity & Fraction & 0.05 \\
\hline Matrix permeability & $\mathrm{mD}$ & 4 \\
\hline Fracture permeability & $\mathrm{mD}$ & 1.67 \\
\hline Initial reservoir pressure & $\mathrm{psi}$ & 1001 \\
\hline Reservoir temperature & ${ }^{\circ} \mathrm{F}$ & 127.4 \\
\hline
\end{tabular}

Subsequently, the comparison of primary CBM production (four producer wells) and ECBM method (four producer wells + one injector well) was analysed by performing production forecasting until PSC ends (2047). Reservoir parameters are presented in Table 1.

The Langmuir adsorption model (Langmuir isotherm) defines the relationship between gas concentration and pressure for each coal. The gas concentration (sorption capacity) increases with coal rank. Low-rank coals (lignite and sub-bituminous coals) have been submitted to low pressure and temperature conditions and still have a low carbon content and high moisture. On the other hand, high-rank coals (semi-anthracite and anthracite), after a long coalification process, have high carbon content and low moisture. In the middle of the range, medium rank 
coals (bituminous coals) show good carbon content. Methane isotherm data were based on typical coal values from actual Basins while $\mathrm{CO}_{2}$ and $\mathrm{N}_{2}$ isotherms were derived from relationships obtained from [10]. Table 2 and Figure 3 summarizes the Langmuir volume and pressure implemented in the model.

Table 2. Langmuir parameters

\begin{tabular}{|l|c|c|c|c|}
\hline \multicolumn{1}{|c|}{$\begin{array}{c}\text { Langmuir } \\
\text { Parameters }\end{array}$} & Unit & $\mathbf{C O}_{\mathbf{2}}$ & $\mathbf{C H}_{\mathbf{4}}$ & $\mathbf{N}_{\mathbf{2}}$ \\
\hline $\begin{array}{l}\text { Max. gas } \\
\text { content, } \\
\text { Langmuir vol. } \\
\text { constant }\end{array}$ & SCF/Ton & 1176.54 & 256.002 & 240 \\
\hline $\begin{array}{l}\text { Langmuir } \\
\text { pressure } \\
\text { constant }\end{array}$ & psi & 818.38 & 859.66 & 1000 \\
\hline $\begin{array}{l}\text { Initial gas } \\
\text { composition }\end{array}$ & Fraction & 0 & 1 & 0 \\
\hline $\begin{array}{l}\text { Initial gas } \\
\text { content }\end{array}$ & SCF/Ton & - & 137.724 & - \\
\hline $\begin{array}{l}\text { Equilibrium } \\
\text { pressure at } \\
\text { initial gas } \\
\text { content }\end{array}$ & psi & - & 1001 & - \\
\hline
\end{tabular}

Pure component Langmuir curves
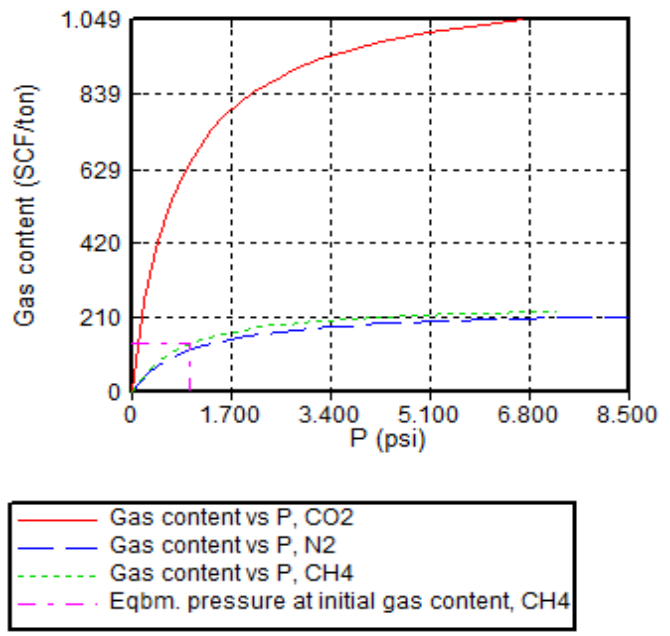

Fig. 3. Langmuir Curves South Sumatra CBM

Table 3. CBM development scenarios

\begin{tabular}{|c|c|c|c|}
\hline \multirow{2}{*}{ Case } & \multicolumn{2}{|c|}{ Composition } & \multirow{2}{*}{$\begin{array}{c}\text { Injection Rate } \\
\text { (MMSCFD) }\end{array}$} \\
\cline { 2 - 3 } & $\mathbf{C O}_{\mathbf{2}}$ & $\mathbf{N}_{\mathbf{2}}$ & 0.05 \\
\hline 1A & 100 & 0 & 0.10 \\
\hline 1B & 100 & 0 & 0.20 \\
\hline 1C & 100 & 0 & 0.05 \\
\hline 2A & 0 & 100 & 0.10 \\
\hline 2B & 0 & 100 & 0.20 \\
\hline 2C & 0 & 100 & 0.05 \\
\hline 3A & 50 & 50 & 0.10 \\
\hline 3B & 50 & 50 & 0.20 \\
\hline 3C & 50 & 50 & \\
\hline
\end{tabular}

Some scenarios were then conducted in order to examine the performance of ECBM. For all scenarios, the reservoir was produced at $150 \mathrm{psi}$ (bottom hole) and gas flow rate at $0.025 \mathrm{MMSCFD} /$ well. In the middle of production years, production wells are set to be closed and begin to be injected by various gas mixes and rates for one year. The cases evaluated as Table 3 .

\subsection{Basic assumptions}

The basic assumptions are:

1. The absence of aquifer flow to the reservoir

2. The Langmuir Isotherm curve is constant in value on each model grid

3. The hydrocarbon gas component in the fluid model is composed of $100 \%$ methane without moisture or ash

4. The permeability and porosity of the reservoir are homogeneous at all reservoir layers.

5. Injection starts after dewatering stage completed

The model estimated Initial Gas in Place (IGIP) is 694,02 MMSCF.

\section{Results and discussion}

The objective of the parametric study was to determine if an optimum mixture and rate of $\mathrm{CO}_{2}$ and $\mathrm{N}_{2}$ could be reached to improve methane production (ECBM) for CBM Field in South Sumatra. Different injection compositions and rates were investigated. The following section presents the results.

\subsection{Base case}

Before investigating the enhanced recovery sensitivity, it is necessary to determine the primary production simulations results. Production plot result for the base case of South Sumatra CBM is presented in Figure 4 and 5. According to the production simulation results (Figure 4) from 2022 until 2047, total cumulative $\mathrm{CH} 4$ production with primary CBM production is about $449.02 \mathrm{MMSCF}$ with a recovery factor of $64.70 \%$. As can be seen in Figure 5 , production rate decreases after 4 years of plateau. At a reservoir pressure of 311 psi (2032), the reservoir is only capable of producing $\mathrm{CH} 4$ with a flow rate of 0.05 MMSCFD which is half of the applied production rates. This number could be increased by implementing enhanced recovery technology in the year of 2032. This is based on the effectiveness of the injection after dewatering stage completed and the drastic reduction of production rates.

\subsection{Case 1, 2 and 3}

Under the constraints applied (800 psi maximum flowing bottom hole pressure and $0.05-0.2$ MMSCFD maximum injection rate), a range of $\mathrm{CO}_{2}-\mathrm{N}_{2}$ mixtures was injected over a year (2032-2033). In order to evaluate the performance of the ECBM, the values assigned in each case are summarized in a table. To simplify the study, 
three base cases were selected and examined to analyze the performance of the ECBM as highlighted in Table 4. The result, shown in Figure 6, indicate that $100 \% \mathrm{~N}_{2}$ provides the greatest methane recovery, followed by the $50 / 50$ mixture, lastly $100 \% \mathrm{CO}_{2}$.

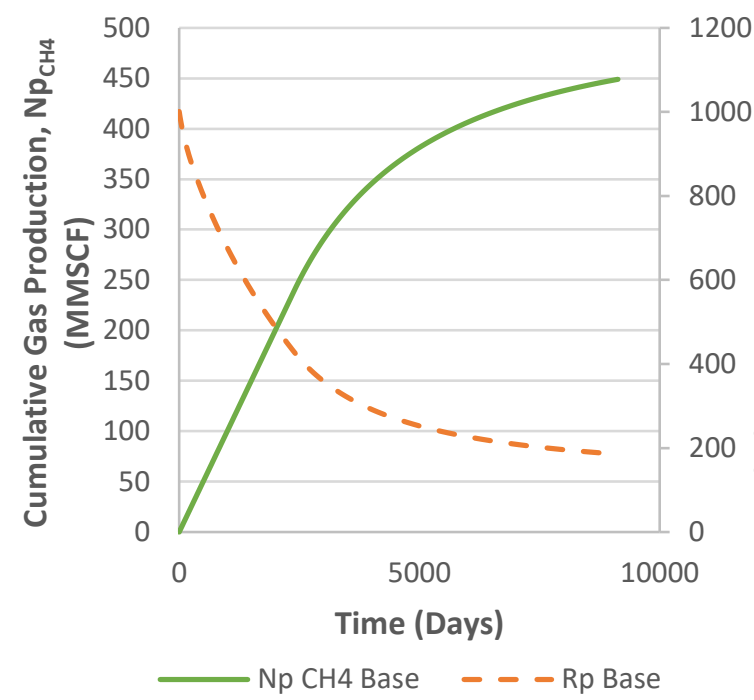

Fig. 4. Cumulative gas production and pressure decline curve
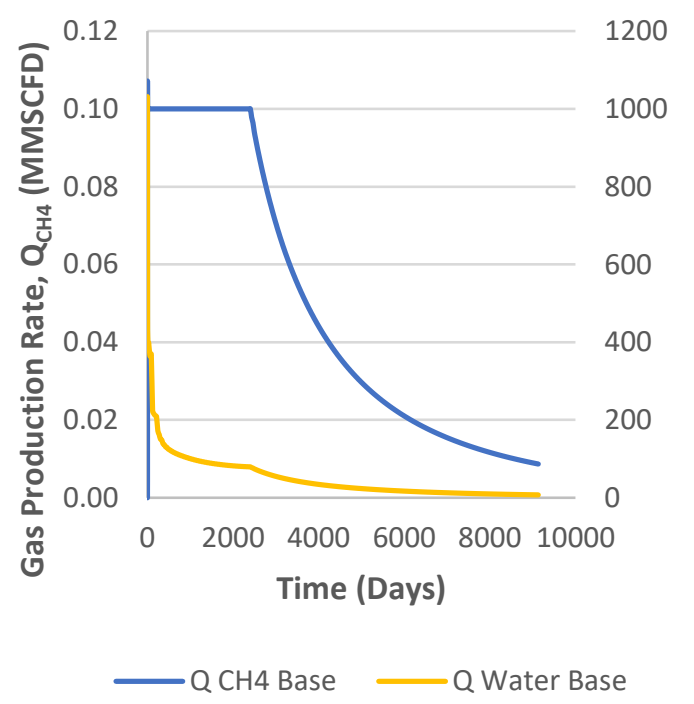

Fig. 5. Production profile

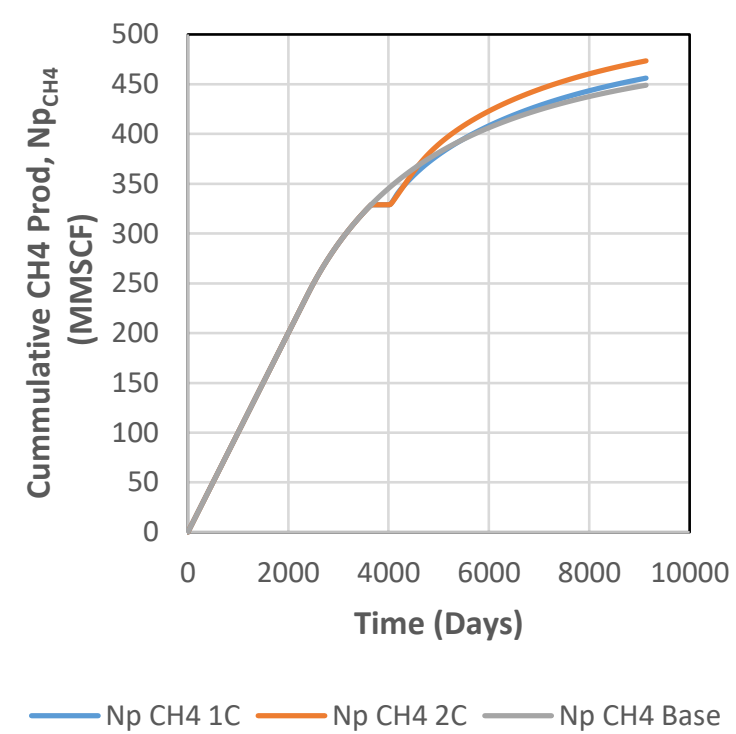

Fig. 6. Cumulative production comparison

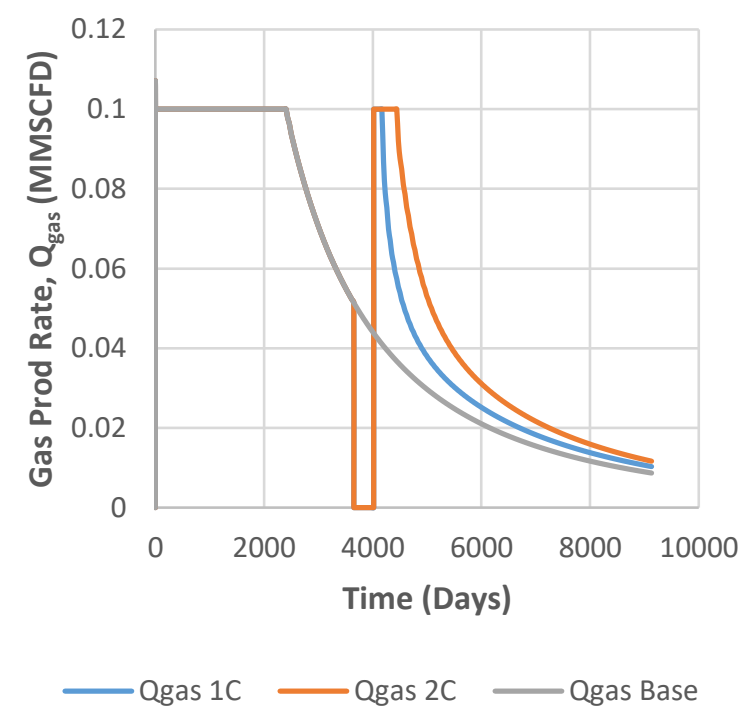

Fig. 7. Gas production rate comparison

The best scenario can obtain additional recovery factor about $3.52 \%$ compared to primary production (base case). Since the 50/50 mixture falls between the results for each gas individually, further analysis was limited to $100 \% \mathrm{~N}_{2}$ or $100 \% \mathrm{CO}_{2}$.

It is observed that the injection of $\mathrm{CO}_{2}$ has resulted in incremental recovery over primary recovery. It is noted that an incremental methane recovery of approximately $1.02 \%$ resulted from $\mathrm{CO}_{2}$-ECBM operations. A pilot project undertaken by Reeves S. and Oudinot K (2005) in San Juan Basin, Allison Unit, with 16 production wells and 4 injection wells, predicted an increase of $4-20 \%$ methane production by $\mathrm{CO}_{2}$-ECBM for 15 years of injections. The small increase in methane production by this study can be attributed to several things. In addition, small volumes of injections (Reeves and Oudinot, 2005) and differences in characteristics of Indonesian and 
American coal reservoirs (Katyal et al., 2007). The type of coal reservoir studied is classified into high-rank coal while in Allison Units categorized as medium rank coal. The most influencing characteristics are the permeability and initial pressure of the reservoir. The differences of permeability $(1,43 \mathrm{md})$ and reservoir initial pressure (1000 psi) of the CBM ' $\mathrm{T}$ ' South Sumatra reservoir hypothetical model with the model at Allison Unit (permeability: $100 \mathrm{md}$ and reservoir initial pressure: 1650 psi) were significant. The higher permeability and pressure, the higher methane that could be obtained and the plateau reservoir will be longer.

According to Karine Schepers et al. (2010), injecting $\mathrm{CO}_{2}$ continuously into the reservoir will cause severe damage to the permeability caused by swelling in the coal matrix so $\mathrm{CO}_{2}$ will be more easily adsorb. The process of adsorption causes the $\mathrm{CO}_{2}$ to bond to the coal causing the $\mathrm{CO}_{2}$ to be physically and permanently trapped on the coal provided sufficient pressure is maintained. Subsequently, $\mathrm{CH}_{4}$ is replaced by injected $\mathrm{CO}_{2}$ and desorbed from the coal matrix and it then flows through the matrix into the natural fracture network. $\mathrm{CH}_{4}$ travels to the lower pressure area where the production well is located and is produced.

For equal injection volumes, on the other hand, $\mathrm{N}_{2}$ will recover more methane. It is forecasted that up to 473.47
MMSCF or about $3.52 \%$ additional methane recovery could be achieved. The pilot project by Reeves and Oudinot (2003) in the San Juan Basin, Tifanny Unit, with 34 production wells and 12 injection wells projected an increase in methane recovery by $\mathrm{N}_{2}$-ECBM by $20 \%$ $40 \%$. Besides the differences in permeability and reservoir initial pressure, the rate of $\mathrm{N}_{2}$ injection and the ratio number of production wells and injection wells affected the results. In the Tiffany Unit, the maximum injection rate of $\mathrm{N}_{2}$ reaches 26 MMSCFD while in this study the maximum injectivity rate of injection rate reaches only 0.2 MMSCFD due to the rule of thumb maximum injection rate.

As seen in Figure 6, the model with $\mathrm{N}_{2}$ Injection resulted in the higher production rate of $\mathrm{N}_{2}$ than $\mathrm{CH}_{4}$. It could be noticed that $\mathrm{N}_{2}$ tends to breakthrough to the producing wells early whereas $\mathrm{CO}_{2}$ does not. The adsorbed methane migrates into the cleats and is produced, while some $\mathrm{N}_{2}$ remains in the cleats and is reproduced (early breakthrough). $\mathrm{N}_{2}$ stays in the cleats due to its lower adsorptivity as compared to methane. As only a some of the portion of the injected $\mathrm{N}_{2}$ gets adsorbed, the coal matrix shrinks, the cleats open, and there is a resultant increase in the coal porosity and permeability, which facilitates injection.

Table 4. Performance of the ECBM based on scenarios

\begin{tabular}{|c|c|c|c|c|c|c|c|c|c|}
\hline \multicolumn{2}{|c|}{ Cases } & \multirow{2}{*}{$\begin{array}{c}\begin{array}{c}\text { Rate of } \\
\text { Injection } \\
\text { (MMSCFD) }\end{array} \\
-\end{array}$} & \multirow{2}{*}{$\begin{array}{c}\begin{array}{c}\text { Cum. } \\
\text { Injected } \\
\mathrm{CO}_{2}\left(\mathbf{f t}^{3}\right)\end{array} \\
- \\
\end{array}$} & \multirow{2}{*}{$\begin{array}{c}\text { Cum. } \\
\text { Injected } \\
\mathrm{N}_{2} \\
\text { (MMSCF) } \\
- \\
\end{array}$} & \multirow{2}{*}{$\begin{array}{c}\mathrm{Cum}_{\mathrm{CO}}^{\mathrm{CO}_{2}} \\
\text { Production } \\
\text { (MMSCF) }\end{array}$} & \multirow{2}{*}{$\begin{array}{c}\begin{array}{c}\text { Cum. } \mathbf{N}_{2} \\
\text { Production } \\
\text { (MMSCF) }\end{array} \\
-\end{array}$} & \multirow{2}{*}{$\begin{array}{c}\begin{array}{c}\text { Sequestered } \\
\mathrm{CO}_{2} \\
(\mathrm{MMSCF})\end{array} \\
-\end{array}$} & \multirow{2}{*}{$\begin{array}{c}\begin{array}{c}\mathrm{Cum} . \mathrm{CH}_{4} \\
\text { Production } \\
\text { (MMSCF) }\end{array} \\
449.02 \\
\end{array}$} & \multirow{2}{*}{$\begin{array}{l}\text { RF } \\
\text { (\%) }\end{array}$} \\
\hline Base & & & & & & & & & \\
\hline \multirow{3}{*}{1} & $\mathrm{~A}$ & 0.05 & 18.30 & - & 4.23 & - & 14.07 & 448.59 & 64.64 \\
\hline & $\mathrm{B}$ & 0.1 & 36.50 & - & 7.63 & - & 28.87 & 451.15 & 65.01 \\
\hline & $\mathrm{C}$ & 0.2 & 71.72 & - & 13.02 & - & 58.69 & 456.13 & 65.72 \\
\hline \multirow{3}{*}{2} & $\mathrm{~A}$ & 0.05 & - & 18.30 & - & 10.56 & - & 452.50 & 65.20 \\
\hline & $\mathrm{B}$ & 0.1 & - & 36.40 & - & 19.32 & - & 460.30 & 66.32 \\
\hline & $\mathrm{C}$ & 0.2 & - & 69.77 & - & 35.64 & - & 473.47 & 68.22 \\
\hline \multirow{3}{*}{3} & $\mathrm{~A}$ & 0.05 & 9.15 & 9.15 & 2.78 & 5.08 & 6.37 & 450.61 & 64.93 \\
\hline & $\mathrm{B}$ & 0.1 & 18.23 & 18.23 & 4.33 & 9.62 & 13.90 & 455.84 & 65.68 \\
\hline & $\mathrm{C}$ & 0.2 & 35.49 & 35.49 & 5.98 & 17.83 & 29.51 & 465.97 & 67.14 \\
\hline
\end{tabular}

\section{Conclusions}

Based on the results from this study, the following conclusions have been drawn. The IGIP from the model is equal to 694.02 MMSCF. The model forecasted 449.02 MMSCF with a recovery factor of $64.70 \%$ by primary production. For this model, $\mathrm{N}_{2}$-ECBM provides the greatest methane recovery, followed by Mixture-ECBM and lastly, CO2-ECBM. The application of $\mathrm{N}_{2}$ injection in South Sumatra CBM field can obtain an incremental methane recovery up to $3.5 \%$.

We express our gratitude to the Universitas Indonesia which has funded this research through the scheme of Hibah Publikasi Internasional Terindeks untuk Tugas Akhir Mahasiswa (PITTA) No.2358/UN2.R3.1/HKP.05.00/2018

\section{References}

1. Kementerian Energi dan Sumber Daya Mineral (KESDM), Peta Jalan Kebijakan Gas Bumi Nasional 2014-2030, (2014)

2. S. Perera, \& P.G. Ranjith. Enhanced Coal Bed Methane Recovery: Using Injection of Nitrogen and Carbon Dioxide Mixture. 1-19. DOI: 10.1002/9781118991978.hces218, (2015)

3. Irawan, Y., Juliana, I., Adilina, I.B., Alli, Y.F, Aqueous Stability Studies of Polyethylene Glycol and Oleic Acid-Based Anionic Surfactants for Application in Enhanced Oil Recovery through Dynamic Light Scattering. International Journal of Technology. Volume 8(8), pp.1414-1421, (2017)

4. EPA, Coal Bed Methane Outreach Program, Enhanced CBM/CMM Recovery, Environmental Protection Agency, Washington, DC, (2002) 
5. S. Reeves. Geological Sequestration of $\mathrm{CO} 2$ in Deep, Unmineable Coal Beds: An Integrated Research and Commercial Scale Field Demonstration Project. Annual Technical Conference and Exhibition, Society of Petroleum Engineers New Orleans, LA, (2001)

6. E. Pratama, M.S. Ismail, S. Ridha, Clean Techn Environ Policy, 20: 581. https://doi.org/10.1007/s10098-017-1383-4, (2018)

7. S. Reeves, R. Gonzalez, K. Gasem, J. Fitzgerald, Z. Pan, M. Sudibandriyo, R. Robinson,Measurement and Prediction of Single-and Multi-Component Methane, Carbon Dioxide and Nitrogen Isotherms for U.S. Coals, Paper 0527, presented at the International Coalbed Methane Symposium, (2005)

8. K. Schepers, A. Oudinot, N. Ripepi, Enhanced gas recovery and $\mathrm{CO} 2$ storage in coal bed methane reservoirs: optimized injected gas composition for mature basins of various coal rank. AAPG Eastern Section meeting, Washington, DC (2011)

9. I.B. Sosrowidjojo, A. Saghafi, Development of the first coal seam gas exploration in Indonesia: Reservoir properties of the Muaraenim Formation, South Sumatra: International Journal of Coal Geology, 79, 145-156, (2009)

10. S.H. Stevens, D. Spector, P. Riemer, Enhanced Coalbed Methane Recovery Using CO2 Injection: Worldwide Resource and $\mathrm{CO} 2$ Sequestration Potential, SPE 48881, presented at the 1998 SPE International Conference and Exhibition in China held in Beijing, China, 2-6 November, (1998)

11. S. Reeves, A. Oudinot, The Allison Unit CO2-ECBM Pilot - A Reservoir and Economic Analysis, International Coalbed Methane Symposium, Tuscaloosa, Alabama, (2005)

12. S. Reeves, A. Oudinot, The Tiffany Unit N2-ECBM Pilot - A Reservoir and Economic Analysis, International Coalbed Methane Symposium, Tuscaloosa, Alabama, (2005)

13. S. Katyal, Valix, Marjorie \& K. Thambimuthu, Study of Parameters Affecting Enhanced Coal Bed Methane Recovery, Energy Sources Part A-recovery Utilization and Environmental Effects. 29. 193-205. 10.1080/009083190965433, (2007) 